\title{
Ambar: A Competence-Evaluating System for Preschool Children
}

\author{
Elena Fabiola Ruiz Ledesma\#, Laura Ivoone Garay Jiménez ${ }^{*}$, Chadwick Carreto Arellano ${ }^{\#}$ \\ \# Ciencias Básicas Departmen, Instituto Politécnico Nacional, Escuela Superior de Cómputo, Juan de Dios Bátiz s/n esq. \\ Othón de Mendizabal, Col. La Escalera, Gustavo A. Madero Mexico City, 07320, Mexico \\ E-mail: efruiz@ipn.mx
}

\begin{abstract}
"Instituto Politécnico Nacional, Unidad Profesional Interdisciplinaria en Ingeniería y Tecnologías Avanzadas, Avenida Instituto Politécnico Nacional No. 2580, Col Barrio la Laguna Ticomán, Gustavo A. Madero, Mexico City. 07340, Mexico

E-mail: garay@ipn.mx
\end{abstract}

\begin{abstract}
This paper describes the development and implementation of AMBAR: an evaluation system whose objective is to measure children's competence achievement during the early childhood better, and provide support material according to the child's needs. Based on a predetermined scale, a level of achievement of each competency is assigned to the child, according to said level, the system will provide digital educational resources to the student, as to aid their development and reinforce previously acquired knowledge. After the child has completed their assigned activities, AMBAR will reevaluate their learning, assign them a new level of achievement, and provide new exercises. The system does also generate a results record for every student. The employed methodology was of a mixed nature; qualitative, because of the description of profiles associated to descriptively analyzed categories, and quantitative, given that statistic significant differences $(p=0.5)$ were determined before and after the use of any resources for any of said categories.
\end{abstract}

Keywords - competences; evaluation; expert system; preschool.

\section{INTRODUCTION}

More than two decades after the development of numerous technological applications and the start of the internet, they have become a key element in countless investigations in the educational technology field. Furthermore, the incorporation of information and communication technologies (ICTs) in the education process has represented a research topic in itself; given the didactic and pedagogical work, it requires to succeed in educational programs both in and outside of the classroom.

The use of technology in education offers a wide range of opportunities to stake out the interaction process between students and knowledge. Even though, several inconveniences have been pointed out, as little common activity between student, teacher, and device, as well as the isolation of the student from teamwork activities. On the other hand, many benefits have been reported, such as the integration of information through different formats (video, audio, text, and animation), granting the student access to large quantities of data, custom work times, and immediate response to the student's progress. These benefits can be achieved through the use of expert systems, [1], [2].

The implications of the use of ICTs as a change in the teaching-learning process would allow a third, technological component to be added to it [3], [4]. The integration of this component requires the designing of new pedagogical strategies, use of new media, posing new activities and acquiring control over the media connecting teachers and students. In this new era of learning, education must be adjusted to the new conditions associated with mobile technology. This paper presents the development of a mobile computational system, which allows the evaluation of kindergarten students' development on their competencies to provide them with digital learning resources. Therefore, the theoretical framework supporting this research corresponds to the three disciplines that came together for the creation of AMBAR: Software Engineering, Artificial Intelligence, and Pedagogy.

The article is divided into six sections which will consist of some issues. Firstly, the formulation of the research statement and its justification is presented. Then an Introduction of research background; reference to IPN's Childhood Development Centers called Centros de Desarrollo Infantil (CENDI) [5]. Is made due to one of these being host the field work necessary for AMBAR's creation. In the third section, a deep explanation of the theoretical background. Due to the multidisciplinary nature of this work, aspects of Software Engineering are presented when considering the different stages suggested for the computational system's creation. Several pedagogical aspects are also included when explaining the different tasks 
that are to be performed by the children. Computational aspects are mentioned due to AMBAR being a computational system based on an expert system. In the fourth section, the methodology is described. In the fifth sections, the results and their analysis are shown, and finally, the Conclusions are presented.

\section{A. Research Problem}

The Instituto Politécnico Nacional (IPN) runs five Childhood Development Centers (CENDI), where children from forty-five days of age to a five years, eleven months old care for (COCENDI) [6]. Children from CENDI's third grade of Kindergarten (around five years old) took part in this research as study subjects, being them the target users of AMBAR.

Until 2014, all the CENDI units had limited access to technological learning support due to the lack of digital educational resources that would support competence development in children according to the Preschool Program (COCENDI) [5-6], emitted by the Public Education ministry named Secretaria de Educación Pública [7]. With the help of the CENDI coordinators (COCENDI), researchers from IPN's Computer Network's Educative Computing area formulated a project called "Desarrollo de recursos educativos digitales y paradigma de ambiente de aprendizaje apoyado en TIC para los CENDI del IPN" (Development of educational resources and learning environment paradigma supported by ICTs in IPN's CENDIs).

Said project was also multidisciplinary, and was carried out between 2014 and 2015 [8], and had as a purpose to significantly stake out and nurture how ITCs have been incorporated to CENDI units. To that effect, several digital educational resources were developed, all of them with the intent of allowing competence development in kindergarten students and according to the six thematic axes of the Preschool Program: Language and Communication, Mathematical Thinking, Exploration and Knowledge of the World, Health and Physical Development, Personal and Social Development, and Artistic Expression and Appreciation. However, the creation of a system that would automatically provide the student with the correct materials for their competence development was overlooked, as well as the development of a scale of difficulty for said material. According to the importance assigned to ITCs in education [9]-[11]. Mobile applications can motivate learning in students as well as allowing for overcoming all the problems that usually surge in classrooms due to the large profile diversity. As stated in Lynn [12], the characteristics of an evaluation system for preschool students to be considered are clear instructions, both recorded in audio and in the text; attractive colors and correct spacing between the icons.

\section{B. General objective}

To develop a digital evaluation system using mobile computer technology, to identify performance levels in the sub-categories that have been proposed for the users, and offer adequate working environments using an expert system for resource assignment.

To achieve the general objective, for specific objectives were proposed:
- To design questionnaires about the competences the children have to develop (working categories).

- To define sub-categories and their associated performance levels.

- To build a system for decision making, which would be able to assign adequate digital resources to each student.

- To validate the system's usability and verify its efficiency.

Several topics correspondent to various disciplines were addressed as to develop an evaluation system (AMBAR). Due to it basing its decision-making on offering each child resources so to help strengthen their capacities and abilities, the expert system was required to consider the pedagogical criteria that are used by teachers in the preschool educational level. The constructionist theory of Papert [13], [14] and the Preschool Program proposed by the SEP [15], were considered as guidelines. On the area of Software Engineering, the system was built on a waterfall model and programs such as javascript, PHP and MySQL were used [16], [17].

\section{MAterial AND METHOD}

Qualitative research, backed up by statistical analysis, was carried out. According to Hernández-Sampieri et al. [18], this method allows to record and analyze the followed procedures during the time of the study. Using the four specific objectives that were set above, and which were also included in the phases of the waterfall model that was followed for the building of the AMBAR system, the research was divided into the following stages: System Analysis and determination of requisites, design, and implementation, and concept tests.

\section{A. System Analysis and determination of requisites}

In the analysis stage, the team worked on the psychopedagogical aspects of the questionnaires and the subcategories that were to be determined for AMBAR. Just as well, technological infrastructure aspects were analyzed, and thus several activities were developed corresponding to the two first specific objectives. After several meetings with COCENDI personnel and with the teacher in charge of the study group, two of the competencies were worked on: Deciding and Telling Apart, which were also denominated as categories. Telling Apart was then divided into four subcategories: colors, shapes, sizes and English words. Deciding was split into two subcategories, which were choosing your clothes and Everyday Activities. Then the following specifically profiles were defined, considering the subcategories and assigning each a level of performance to measure the student's learning.

- Profile 1: Telling apart colors. (Low and high level).

- Profile 2: Telling apart shapes. (Low and high level).

- Profile 3: Telling apart sizes. (Low and high level).

- Profile 4: Telling apart English words. (Low and high level).

- Profile 5: Choosing clothes to wear. (Low and high level). 
- Profile 6: Choosing everyday activities. (Low and high level).

Based on these profiles, six questionnaires were built, one per subcategory. To decide the level in which each child would be allocated, it was considered that, if they were able to answer at least $70 \%$ of a questionnaire correctly, their level would be high. On the other hand, if they did not reach the $70 \%$ mark, their level of knowledge on said subcategory would be considered as low. All the information from these questionnaires was registered and stored in the system's database. Every time a child finished a questionnaire, they were given the option to continue with the next one or to perform a different activity. If they chose to change their activity, the system would then evaluate their profile and assign them digital educative resources that would allow them to strengthen their lowest ranked abilities.

As for the assignment of said digital resources, the system employed the knowledge base that was built according to the amount of correct and incorrect answers. These rules then became the system's core for decision-making. The reason for it to be a rule-based system was that due to preschoolers not being able to give as complex answers as older students, those they gave could be interpreted as yes or no answers. Therefore, the system does not perform complex analysis of the children's responses.

\section{B. Design and implementation}

Some interfaces from the AMBAR system are shown in Figures 2 and 3. For a child to access the system, a username and password set is required. In this case, their username would be their names, which could be written by either their teacher or tutor. However, as not all five-year-olds are yet capable of writing, their password was made up from the selection of three animal images which were associated with their user accounts as in Fig. 1.

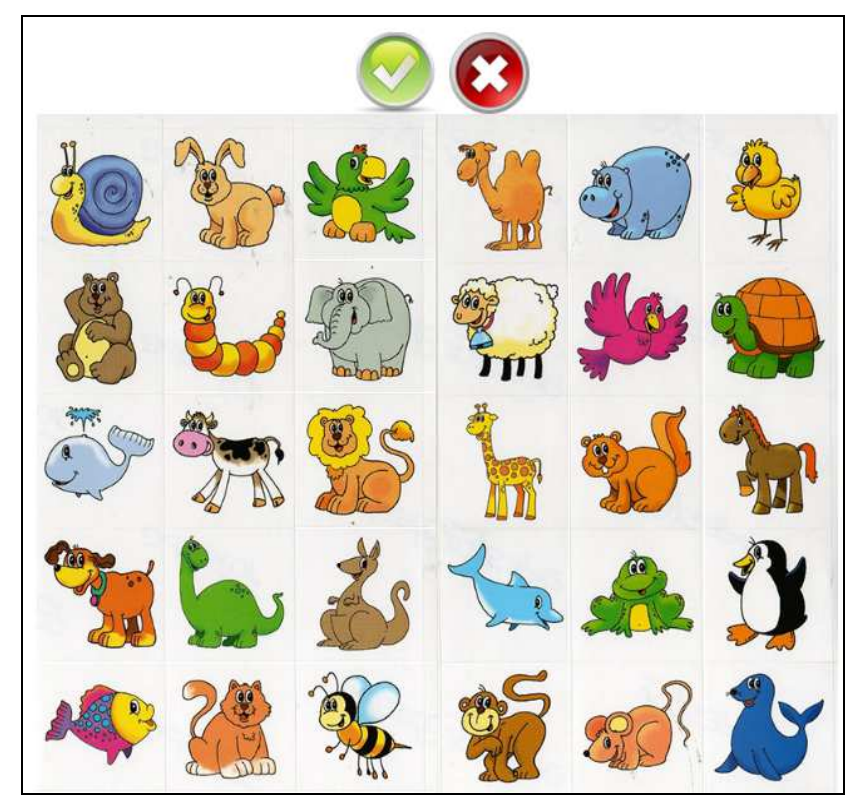

Fig. 1 Access to the system by selecting a pattern

A teacher user has a typical username and password set, as shown in Fig. 2.

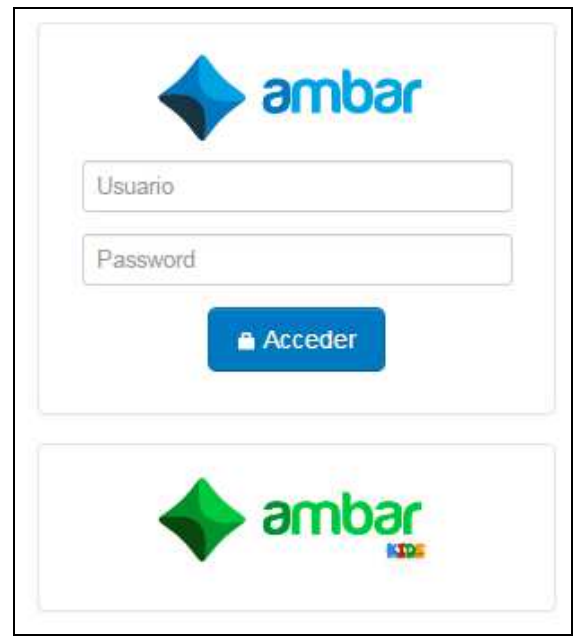

Fig. 2 Access to AMBAR

After a child logs in, they can select to work with one of the two available activities (categories) they are offered: Deciding or Telling Apart. (See Fig. 3). Once one of them has been selected, they must also choose a subcategory of the four available, as shown in Fig. 4.

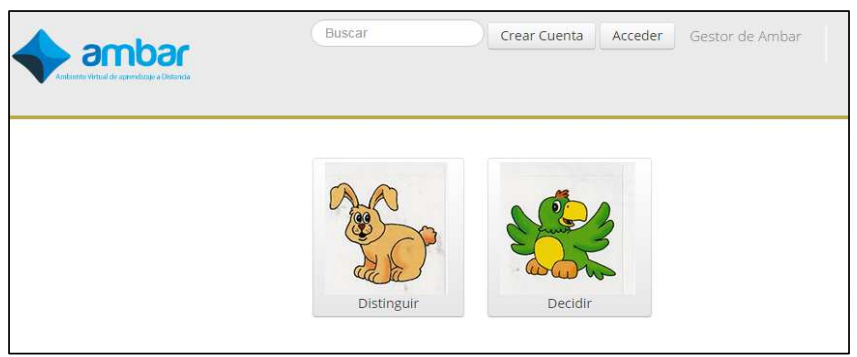

Fig. 3 Activity Selection Interface

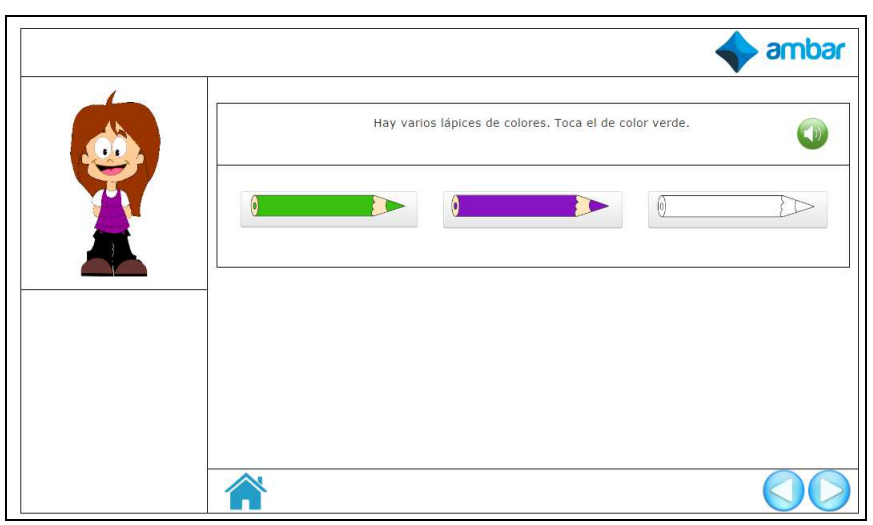

Fig. 4 Interactive interface for selecting the required color

\section{Testing}

Once AMBAR was fully built, a qualitative analysis was performed to evaluate the system's functionality, as well as to deepen in aspects corresponding to the child's evaluation process. The fourth study objective reported in this document refers to system usability and is linked to the stage of model tests from the waterfall model that was used in AMBAR's construction. Usability tests refer to system functioning, its ease of use and the user's satisfaction degree. For the usability tests, Córdova-Pérez et al. [19], Donker \& Markopoulos [20], were taken as a reference. According to 
them, these are the steps to follow when performing tests with children:

1) Planning. The number of participants is specified, as well as their ideal conditions for working with educational technology.

2) Execution. The place, test conditions, and observation protocols are specified for the interaction of children with the system.

3) Evaluation. The results are quantified, and the system's level of satisfaction is determined.

\section{Planning}

The student sample group consisted of ten children in their third grade of kindergarten, this being the size of a common group in the "Margarita Erro" CENDI unit, where the tests were performed. The reason for choosing thirdgrade students was that the educational program emitted by the SEP indicates that English is taught as of that year. Therefore, these students were expected to develop competencies such as the recognition of some words and identification with the English language. Furthermore, due to the availability of digital resources directed to developing for said competences, their inclusion in AMBAR was highly convenient. A questionnaire that would be applied by the teacher was developed to have a first approach to the students. Each child answered questions related to software use and their approach to computational programs, as well as their use of mobile devices, which would be used in the tests. This enabled the research team to have a better idea of the familiarity of the subjects with digital resources. In Table 1, the questions employed for the questionnaire can be appreciated:

TABLE I

SCRIPT FOR DE INITIAL INTERVIEW APPLIED TO THE TEN CHILDREN IN THE SAMPLE GROUP

\begin{tabular}{|c|c|}
\hline $\begin{array}{l}\text { The script of the interview } \\
\text { made to third-year preschool } \\
\text { students. }\end{array}$ & $\begin{array}{l}\text { ( ) Identifying geometric } \\
\text { figures. } \\
\text { ( ) Identifying animal sounds. } \\
\text { ( ) Singing }\end{array}$ \\
\hline Have you used a desktop? & ( ) Counting. \\
\hline $\begin{array}{c}\text { Yes } \quad \text { No } \\
\text { Have you used a laptop? }\end{array}$ & $\begin{array}{l}\text { ( ) Identifying animal names in } \\
\text { English. }\end{array}$ \\
\hline $\begin{array}{c}\text { Yes No } \\
\text { Have you used a tablet? }\end{array}$ & $\begin{array}{l}\text { ( ) Identifying body parts. } \\
\text { ( ) Identifying clothing items. }\end{array}$ \\
\hline $\begin{array}{c}\text { Yes No } \\
\text { Have you played on a tablet? }\end{array}$ & $\begin{array}{l}\text { ( ) Telling apart colors. } \\
\text { ( ) Telling apart shapes.. }\end{array}$ \\
\hline $\begin{array}{c}\text { Yes No } \\
\text { What have you played? }\end{array}$ & ( ) Telling apart sizes. \\
\hline
\end{tabular}

\section{E. Execution}

The tests were carried out in the unit's playground to monitor the test's development in a more relaxed environment. The following resources were used:

- Two tables

- Ten chairs

- Five iPad

- Five iPad mini 4

- Three Samsung Galaxy Tab 8.9 tablets

- One Sony Vaio laptop

- Internet connection
Before starting the tests, the internet connection had to be verified in every mobile device. All students used Google Chrome as an internet explorer. The teacher in charge of the group, who had been previously instructed on how to explain the operation of AMBAR, was responsible for interacting with her students while the researchers observed. Due to the attention period of young children being an an average of twenty minutes, they were asked to solve the first three initial questionnaires on the first day and finish the following three on the next day. The average solving time for each questionnaire was of three minutes. Three more minutes per child were included for the previous interview.

In the eight sessions that followed after the initial evaluation, the children were asked to play with the educational resources that the system provided them according to their results in the initial evaluation. Each session lasted for twenty minutes. After a lapse of two weeks of daily sessions, the children were asked to perform the initial evaluation once more. It should be noted that the questions were not the same, as the system randomly chooses its questions from its reagent bank. All of the sessions were carried out during ordinary class days.In Table 2 , the answers that guided the observations on the children's performance are shown:

TABLE II

OBSERVATION RUBRIC

\begin{tabular}{l|l}
$\begin{array}{l}\text { To login by selecting three } \\
\text { images out of the twenty four } \\
\text { that are presented. }\end{array}$ & $\begin{array}{l}\text { Detect from the facial } \\
\text { expression: nervousness or } \\
\text { happiness when finishing a } \\
\text { 1) Selecting a questionnaire. }\end{array}$ \\
$\begin{array}{l}\text { task. } \\
\text { Detect from body language: } \\
\text { Selecting images for }\end{array}$ & $\begin{array}{l}\text { Joy or distress when trying } \\
\text { to select the corresponding }\end{array}$ \\
3) Dragging figure. & item. \\
4) Following voice &
\end{tabular}

Photographs and videos of the subjects interacting with AMBAR were also taken as a means of verification for the results in the rubrics, aiming to analyze the subjects' nonverbal language further. It should be noted that, due to the subjects being minors, it was necessary to ask for both their tutors and the unit's permission to take a photograph and video. They were also notified that said information was to be used exclusively for academicals means and that the students' confidential information was never to be used. All the information was safeguarded by the head researcher in charge of the protocol.

\section{RESULTS AND DISCUSSION}

The results for the four planned objectives are shown below. Both the first and the second refer profile detection and building, which was carried out through working with a teacher and a pedagogue. The third objective concerns the correct assignment of digital learning resources, according to the detected student profiles. The fourth objective relates to system usability.

\section{A. Results Obtained from Student Profile Detection and Building}

The profiles' building phase required of several parameters such as the time spent in observing the students 
for the obtaining of their behaviors, aptitudes, attitudes, and moods. The said procedure took an average of four months, along with the specialists that intervened in the creation of the questionnaires by contributing with their experience in the handling of preschool children, as to achieve the most adequate and concise questions for them. For this purpose, the children's study habits, learning style, and the teacher's teaching method were taken into account. The result was the profile-building system for AMBAR, same which was considered in the decision-making expert system. The total of students from the five CENDI units who took part in the research was of 164 , of whom $92(56 \%)$ were boys, and $72(44 \%)$ were girls.

\section{B. Results Obtained from the Initial Interview}

In Table 3, the percentages obtained from the children's responses to the initial interview are shown.

TABLE III

QUESTIONS WITH ANSWER PERCENTAGE

\begin{tabular}{|r|c|c|}
\hline \multicolumn{1}{|c|}{ Question } & Yes & No \\
\hline Have you used a desktop? & $40 \%$ & $60 \%$ \\
\hline Have you used a laptop? & $30 \%$ & $70 \%$ \\
\hline Have you used a tablet? & $60 \%$ & $40 \%$ \\
\hline Have you played on a tablet? & $60 \%$ & $40 \%$ \\
\hline
\end{tabular}

About question five about if initially the child exhibits the competence required, the results are shown in Table 4.

TABLE IV

QUESTION WITH ANSWER PERCENTAGE

\begin{tabular}{|r|c|c|}
\hline \multicolumn{1}{|c|}{ Questions } & Yes & No \\
\hline Identifying geometric figures & $40 \%$ & $60 \%$ \\
\hline Identifying animal sounds & $50 \%$ & $50 \%$ \\
\hline Singing & $100 \%$ & $0 \%$ \\
\hline Counting & $40 \%$ & $60 \%$ \\
\hline Identifying animal names in English & $10 \%$ & $90 \%$ \\
\hline Identifying body parts & $50 \%$ & $50 \%$ \\
\hline Identifying clothing items & $10 \%$ & $90 \%$ \\
\hline Telling apart colors & $80 \%$ & $20 \%$ \\
\hline
\end{tabular}

C. Results Obtained on the Assignment of Digital Educational Resources, According to the Detected Profiles.

To know if AMBAR assigned the right digital educative resources according to the detected profile, the student's performance before and after the testing period was analyzed in all six categories. $100 \%$ of the students presented a better performance after the testing period was over. By analyzing as to identify the students' abilities that needed development, the statistical analysis proved that the assignment of digital learning material was adequate in all cases, as every child showed enhancement in their opportunity areas after the final test. Moreover, the teachers observed a general performance improvement in their classes, after using AMBAR. In conclusion, it can be said that the system does provide the student with adequate digital learning resources, according to their detected profile.

According to the student deficiencies detected in the first test, $50 \%$ of the students needed help with English, $40 \%$ in sizes, $20 \%$ in shapes and $10 \%$ in colors. After the system's use, all of them either maintained their maximum evaluation score or presented a certain progress degree in their performance in the deficient areas. Due to the questionnaire contemplating only five evaluation levels, $100 \%$ of the subjects exceeded the minimum required score. In total, the students who improved their scores or maintained them in the highest evaluation level were: $60 \%$ in colors, $90 \%$ in shapes, $70 \%$ in sizes and $80 \%$ in English. In the case of the English performance problem, which seems to affect a large proportion of the students, the pedagogical point of view is discussed ahead.

Antonio had previously contact with a tablet, which he used at home to watch TV movies and series and playing. The teacher in charge of his school group remarked that he is a very extroverted and happy child, but that he has had difficulty with the English subject. In the AMBAR initial test, he obtained low scores for both the identification of English words and shapes. On the other hand, he scored high on distinguishing colors and sizes. AMBAR provided Antonio with three educational resources to help him identify words in English, as well as two more resources for shapes. The materials provided for English were " $L a$ Escuela" (The School), "Tic Tac Christmas," and "El Animalorama" (The Animal Compendium). Interfaces for these resources can be appreciated in Fig. 5.

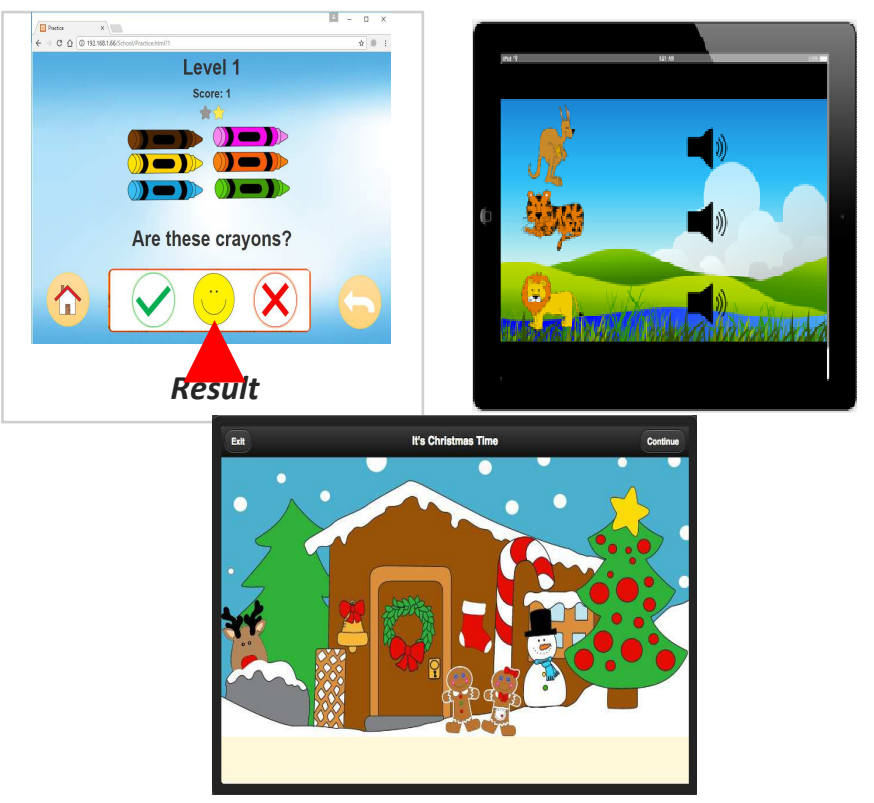

Fig. 5 upper left: "La escuela" (The School). Upper right: Animalorama (The Animal Compendium). Lower center: "Tic Tac Christmas

After completing the two experimental weeks, with daily sessions of twenty minutes each, Antonio made significant progress in his opportunity areas. He was able to associate the correct concepts with their words in English, played memory games, and was able to listen to words and correctly repeat their pronunciation. When he answered the second random control questionnaire, significant progress were 
shown. It should be mentioned that the teacher's intervention was significant in this case, as she always oversees Antonio.

\section{Observations made to students while working with}

AMBAR

As results of the observation of the students, the following facts were found:

- Eighty percent of the subjects were able to access AMBAR via their three-animal password.

- Seventy percent of the subjects followed instructions correctly.

- All the students selected their desired questionnaire correctly.

- $80 \%$ of the students chosen correctly the requested figures after being asked to.

- $100 \%$ of the subjects showed delighted expressions while working with AMBAR.

- $100 \%$ of the subjects seemed focused on what they were doing.

- $70 \%$ of the students wanted to solve again one of the questionnaires they had already solved, but the system did not allow them to. When they asked their teacher why they were answered that they had to continue with the following questionnaires to access the games that would be provided later.

- Twenty percent of the children showed bewilderment when they did not understand an instruction.

- The researchers could hear that around seventy percent of the children would say a figure's name when selecting it as if confirming the action, they were carrying out.

- Thirty percent of the students made mistakes when selecting colors.
- All the children made mistakes when answering exercises concerning words in English, which caused the system to provide them with the three educational resources to help them practice.

- Thirty percent of the children made mistakes while answering the shapes questionnaire.

After the children had worked with AMBAR, a second interview was carried out to measure their level of satisfaction with the system. The questionnaire is shown in Table 5.

TABLE V

USER SATISFACTION QUESTIONNAIRE

\begin{tabular}{|c|c|}
\hline Questions & Questions \\
\hline $\begin{array}{l}\text { 1. - Did you like playing with } \\
\text { AMBAR? } \\
\text { A lot, a little, not at all } \\
\text { 2.-What did you like more? } \\
\text { a) the pictures b) the colours } \\
\text { c) the voice } \\
\text { 3. Was it hard to choose the } \\
\text { correct answers? } \\
\text { A lot, a little, not at all } \\
4 \text { Did you have questions } \\
\text { while you played? } \\
\text { Many, a few, none } \\
\text { Which ones? } \\
\text { 5. Would you recommend it } \\
\text { to a friend? } \\
\text { A lot, a little, not at all } \\
\text { Why? }\end{array}$ & $\begin{array}{l}\text { 6. Would you play again? } \\
\text { A lot, a little, not at all } \\
\text { Why? } \\
\text { 7. Was it easy to select the } \\
\text { colours? } \\
\text { A lot, a little, not at all } \\
\text { 8. Was it easy to select the sizes } \\
\text { you were requested? } \\
\text { A lot, a little, not at all } \\
\text { 9. Was it easy to select the } \\
\text { shapes? } \\
\text { A lot, a little, not at all } \\
\text { 10. Was it easy to select the } \\
\text { words in English? } \\
\text { A lot, a little, not at all }\end{array}$ \\
\hline
\end{tabular}

The answers to the questionnaire presented above are shown in Table 6.

TABLE VI

ANSWERS GIVEN BY STUDENTS ABOUT THE USER SATISFACTION QUESTIONNAIRE

\begin{tabular}{|c|c|c|c|c|c|}
\hline No. & Variable & Dimension & A Lot & A Little & None \\
\hline \multirow{5}{*}{1} & \multirow{5}{*}{ System Utility } & Useful for assimilating knowledge & $100 \%$ & & -------- \\
\hline & & Useful for identifying colours & $90 \%$ & $10 \%$ & -------- \\
\hline & & Useful for identifying shapes & $80 \%$ & $20 \%$ & -------- \\
\hline & & Useful for recognizing sizes & $90 \%$ & $10 \%$ & ------- \\
\hline & & Useful for recognizing words in English & $100 \%$ & ---------- & $\begin{array}{ll}------- \\
\end{array}$ \\
\hline \multirow{5}{*}{2} & \multirow{5}{*}{ User satisfaction } & Satisfaction for knowledge assimilation & $100 \%$ & --------- & ------- \\
\hline & & Satisfaction for colour identification & $100 \%$ & ------- & $\begin{array}{ll}------- \\
\end{array}$ \\
\hline & & Satisfaction fops identification & $90 \%$ & $\begin{array}{ll}------ \\
\end{array}$ & $\begin{array}{ll}------ \\
\end{array}$ \\
\hline & & Satisfaction for size recognition & $90 \%$ & $\begin{array}{ll}------ \\
\end{array}$ & $\begin{array}{ll}------ \\
\end{array}$ \\
\hline & & Satisfaction for the recognition of English Words & $100 \%$ & ------- & ------- \\
\hline \multirow{4}{*}{3} & \multirow{4}{*}{ Ease of use } & Makes assimilating knowledge easier & $90 \%$ & ------ & ------ \\
\hline & & Makes identifying colours easier & $100 \%$ & ------ & ------ \\
\hline & & Makes identifying shapes easier & $90 \%$ & ------- & ------ \\
\hline & & Makes recognizing sizes easier & $90 \%$ & ------ & ------ \\
\hline
\end{tabular}

In resume, all the children found the system enjoyable and liked a lot the animals in it. The figures, in general, were of their liking, as well as the colors and the voice. They as well pointed out that it was easy to use, but that it was necessary to be more explicit when signaling the system's exit, as well as a way of playing it again. Utility, ease of use and user satisfaction for AMBAR are all evaluated via the categories A Lot, A Little and None (See Table 7). 
TABLE VII

UTILITY, EASE OF USE AND USER SATISFACTION FOR AMBAR

\begin{tabular}{|c|c|c|c|c|c|c|}
\hline No & Q1 & Q2 & Q3 & Q4 & Q5 & Q6 \\
\hline 1 & A lot & $\begin{array}{l}\text { Shapes, animals, colors and } \\
\text { shapes. Playing it. }\end{array}$ & A little & $\begin{array}{l}\text { Few. } \\
\text { When I wanted to exit. }\end{array}$ & $\begin{array}{l}\text { A lot. } \\
\text { It is pretty. }\end{array}$ & A little \\
\hline 2 & A lot & Images, animals, and colors. & Not at all. & None & $\begin{array}{l}\text { A lot. } \\
\text { So that they can play. }\end{array}$ & A little \\
\hline 3 & A lot & Animals, voice, and colors & Not at all. & $\begin{array}{l}\text { A little. } \\
\text { To play again. }\end{array}$ & $\begin{array}{l}\text { A little } \\
\text { I liked it. }\end{array}$ & A lot. \\
\hline 4 & A lot & Animals, winning. & A little. & $\begin{array}{l}\text { Few. } \\
\text { When I wanted to exit. }\end{array}$ & $\begin{array}{l}\text { A lot. } \\
\text { Because of the } \\
\text { animals. }\end{array}$ & A lot \\
\hline 5 & A lot & Animals, playing. & Not at all. & None & $\begin{array}{l}\text { A lot. } \\
\text { So that they can play. }\end{array}$ & A lot \\
\hline 6 & A lot & Figures, colors and sizes. & Not at all. & None & $\begin{array}{l}\text { A lot. } \\
\text { To play. }\end{array}$ & A lot \\
\hline 7 & A lot & Colors & Not at all. & Few & A little & A little \\
\hline 8 & A lot & Animals & Not at all. & None & A lot & A lot \\
\hline 9 & A lot & Animals & Not at all. & None & A lot & A lot \\
\hline 10 & A lot & Colors & Not at all. & Few. & A lot & A lot \\
\hline
\end{tabular}

The system's utility was measured through the children's answering of questionnaires before and after having played with the educational resources the system gave them. Each questionnaire consisted of four questions. As it is shown below, in general, AMBAR was evaluated as satisfactory by its target users. The system's utility was measured through the children's answering of questionnaires before and after having played with the educational resources the system gave them. Each questionnaire consisted of four questions. As it is shown below, in general, AMBAR was evaluated as satisfactory by its target users

TABLE VIII

MEASUREMENT OF THE UTILITY OF THE SYSTEM THROUGH ITS USE BY CHILDREN

\begin{tabular}{|c|c|c|c|c|c|c|c|c|}
\hline & \multicolumn{4}{|l|}{ Before } & \multicolumn{4}{|l|}{ After } \\
\hline & Colors & Shapes & Sizes & English & Colors & Shapes & Sizes & English \\
\hline 1 & 0.75 & 0.75 & 0.50 & 0.50 & 1.00 & 1.00 & 1.00 & 0.75 \\
\hline 2 & 1.00 & 1.00 & 0.75 & 0.75 & 1.00 & 1.00 & 1.00 & 0.75 \\
\hline 3 & 0.75 & 0.75 & 0.75 & 0.25 & 1.00 & 1.00 & 1.00 & 0.75 \\
\hline 4 & 0.75 & 0.75 & 0.50 & 0.50 & 0.75 & 1.00 & 1.00 & 1.00 \\
\hline 5 & 0.50 & 0.75 & 0.75 & 0.75 & 1.00 & 1.00 & 0.75 & 0.75 \\
\hline 6 & 0.75 & 0.50 & 0.75 & 0.50 & 1.00 & 0.75 & 0.75 & 0.75 \\
\hline 7 & 0.75 & 0.75 & 0.50 & 0.25 & 1.00 & 1.00 & 1.00 & 0.75 \\
\hline 8 & 1.00 & 0.50 & 0.75 & 0.50 & 1.00 & 0.75 & 1.00 & 1.00 \\
\hline 9 & 1.00 & 0.75 & 0.50 & 0.75 & 1.00 & 1.00 & 0.75 & 0.75 \\
\hline 10 & 1.00 & 0.75 & 0.75 & 0.50 & 1.00 & 0.75 & 1.00 & 1.00 \\
\hline
\end{tabular}

\section{CONCLUSION}

The use of digital educational resources can increase both interest and motivation in students. They also offer a different way of acquiring new knowledge or reinforcing learning, rather than the traditional material that has been used since long ago. This project successfully developed a digital educational resource that can be accessed with any mobile device, with full ease of use and appeal for children always in mind.

With the intention of the digital educational resources that the IPN already owns can be made the most of, it will be necessary for the CENDI units to have both enough mobile devices for all their students, and a fast and secure internet connection. Just as well, further promotion of cyberculture in said campuses will be required. As a final statement, it is considered that, by liberating the use of educative resources, a great input will be made for the improvement of the educative scenario of the children in the IPN community. It must also be noted that the use of images for password generation is an important alternative for the children's stage of development, as it serves them for exercising their memory.

\section{ACKNOWLEDGMENT}

We would like to thank SIP IPN, COFAA, and EDD for the support provided. 


\section{REFERENCES}

[1] I. Abakumova, I. A. Bakaeva, and K. Y. Kolesina, "Technologies of initiating students into independent (self-guided) activity in supplementary distance learning." International Journal of Cognitive Research in Science, Engineering, and Education, vol. 4(2), pp. 1-8, 2016.

[2] A. Badia, L. Chumpitaz, J. Vargas, and G. Suárez, G. "La percepción de la utilidad de la tecnología conforma su uso para enseñar y aprender" REDIE. Revista Electrónica de Investigación Educativa, 18(3), 95-105, 2016.

[3] Stosic, L., "The importance of educational technology in teaching". International Journal of Cognitive Research in Science, Engineering and Education, vol. 3(1), pp. 111-114, 2015.

[4] H. Jaakko, L. Lasse, K. Kristiina, and R. Antii., "Visual tools as mediational means: A methodological investigation". Journal of Early Childhood Research, vol. 15(4), 359-373, 2017.

[5] COCENDI (2010a). Misión y Visión de la COCENDI.

[6] COCENDI (2010b). Programa de Educación Inicial (PEI).

[7] SEP (2011). Programa de Estudio. Guía para la educadora.

[8] ESCOM-IPN. (2016) Laboratorio para el desarrollo de prototipos informático-educativos- Final Report. Registred in SIP. 20141665 México, D.F.

[9] R. Abascal-Mena, and E. López-Ornelas, El uso de m-learning para motivar al alumno en su aprendizaje: caso de estudio en la UAM Cuajimalpa. In C. R. Jaimez, K. S. Miranda, E. Vázquez and F. Vázquez (Eds.), Estrategias didácticas en educación superior basadas en el aprendizaje: innovación educativa y TIC (pp. 46-66). Ciudad de México, México: UAM, 2017.
Salas-Rueda, R. A. (2016). Diseño y análisis de un Sistema web educativo considerando

[10] B. Novkovic-Cvetkovic, \& D. Stanojevic., "Educational needs of teacher for introduction and application of innovative models in educational work to improve teaching." International Journal of Cognitive Research in Science, Engineering, and Education, vol. 5(1), 49-56, 2017.

[11] A. Lynn., "Methodological reflections on the use of systematic reviews in early childhood researc." Journal of Early Childhood Research, vol. 16(1), 18, 2018.

[12] S. Papert., Desafío a la mente: Computadoras y educación. Buenos Aires, Arentina: Editorial Galápago, 1987.

[13] S. Papert, and I. Harel., (2002). Situar el Construccionismo. Traducción del Centro Latinoamericano para la Competitividad y el Desarrollo Sostenible (INCAE). Retrieved June 14, 2017 from, Ihttp://web.media.mit.edu/ calla/web_comunidad/Readings/

[14] SEP (2013). Programa de estudio Preescolar

[15] R. Hernández-Sampieri, C. Fernández-Collado and P. Baptista-Lucio, Metodología de la investigación, $5^{\text {a }}$ ed. México: McGraw-Hill, 2010

[16] Badaró, S., Ibañez, L., \& Agüero, M. (2013). Sistemas Expertos: Fundamentos, Metodologías y Aplicaciones.

[17] Rouse, M. (2017). What is the expert system?. SearchHealthIT.

[18] M. Pérez-Cordoba, M. E. García, and J. A. Hernández, "Consideraciones especiales para realizar pruebas de usabilidad con niños: Caso de Estudio". ReCIBE. Revista electrónica de Computación, Informática Biomédica y Electrónica, vol. 4(1), pp.135-246, 2015

[19] A. Donker, and P. Markopoulos. "A comparison of Think-aloud, Questionnaires, and Interviews for testing usability with children." People and Computers XVI - Memorable, 2002, p. 305-3016. 